\title{
Sex and Symbol in Andalusian Comic Poetry
}

In many areas of western Andalusia, the pre-lenten festival of carnival is the highlight of the ritual calendar, surpassing even the summer feria and Holy Week in enthusiasm among the poor (Rodríguez Becerra, 1985). Although this proletarian celebration has faded away in many areas of Spain since the 1930 s, its traditions remain strong in certain localities, especially in the small towns of rural Andalusia, as well as in the port city of Cadiz. In many rural pueblos, carnival has continued in the face of stringent government prohibitions both before and during the Franco regime (Rodríguez Becerra, 1985:118-119; Mintz, 1982:240). During Andalusian carnival, exuberant villagers masquerade with their faces covered, parade through the streets, pack the bars, sing gossipy or satirical coplas and act out rehearsed skits and pantomimes - many of them scabrous and caustic. In some villages in western Andalusia, there are also organized groups that perform mini-dramas victimizing deviants or lampooning the authorities (Gilmore, 1975; 1988). For this reason Franco outlawed carnival in 1937, although many local authorities turned a blind eye to the merriment, so long as it remained nonviolent.

The high point of Andalusian carnival is probably the musical band, called the murga in Seville Province. Their humorous performances are considered the heart or "spirit" of the festival, and without which carnival has "no souln. Organized weeks before the festival, these bands, usually numbering between five and ten musicians, are led by a "maestro", or master-poet, usually a worker or poor peasant, in the old days often illiterate. The murga troubadours parade through the town's main streets, beating their drums and tooting their horns, while they chant their funny ditties ${ }^{1}$. In keeping with the persecutory tone of the celebration, the lyrics

1 In Fuenmayor, informants report two kinds of murga: estudantiles and chirigotas. The former, which have died out, were "serious" groups singing romances, homilies, and sentimental themes; the latter were comic and spicy" (Gilmore, 1988). Here I am dealing with the chirigota genre. Fieldwork in Spain took place at various times between 1972 and 1991. The following institutions deserve a word of thanks for their financial support: The National Science Foundation, the H. F. Guggenheim Foundation, the Wenner-Gren.Foundation, the Council for International Exchange of Scholars, the 
are alternately satirical, bawdy, and inflammatory. Pitt-Rivers (1971:176) has called attention to the shamelessness of carnivalesque behavior, when "anything goes". In its levity and irreverence, Andalusian carnival shares much with similar festivals throughout the Catholic world. For Europe generally, Kertzer (1988) has provided a splendid historical summary of the political subversiveness of carnival since the Middle Ages, a classic example being found in Le Roy Ladurie's Carnival in Romans (1979) ${ }^{2}$.

Despite its history of political subversion (Checa, 1990) Andalusian carnival is by no means only a ritual of political protest. Its aggressive energies have been unleashed in two ways: vertically against the authorities and horizontally against peer-group deviance. In the latter sense carnival is culturally conservative at the same time it is politically radical (Gilmore, 1987:104-108). Of importance here is the punishment of sexual misconduct in a society deeply concerned with propriety: "The songs of Carnaval are recognized be some to have been the guardian of marital and pre-marital fidelity" (Pitt-Rivers, 1971:177). Much of this cultural sanctioning involves scapegoating deviants, especially promiscuous women, by means of the satirical coplas - a fierce public mockery that virtually ensures life-long disgrace (Mitchell, 1988:104). As summarized by the sociologist (García de Diego, 1960:295), carnival is the administration of "collective justice" when

citizens are publicly censured and their flaws announced, and during which no one is permitted to take offense, and in which the victim must accept the punishment of public shaming and the ridicule of his fellows.

Mitchell (1988:194) refers to carnival as exemplifying the "persecutory mythopoesis" of Spanish folk ritual. This is possibly an overwrought term, but it has some validity, especially when used in reference to carnival coplas criticizing female deviance.

National Endowment for the Humanities, the American Philosophical Society, and the Cultural Program between Spain's Ministry of Culture and United States' Universities. I also want to thank the following Spanish anthropologists for their kind hospitality in Seville: Profs. Salvador Rodríguez Becerra, Isidoro Moreno Navarro, and Alfredo Jiménez Núnez. The following local people were extremely kind and helpful: Bobi Martín Caro, Sebastián Martín Caro, Manoli Fernández, Antonio Milla, Ramón López Morillo, Francisco Fernández, María-Aurora Martín Ruano, and José Martín Ruano. Prof. Daniel Bates and Judith Tucker provided trencherman support during the most recent fieldwork.

2 The classic work on carnival is Caro Baroja (1965). For more recent studies on Andalusian carnival see articles by Aguilar (1983), González Troyano et al. (1983), Almagro et al. (1990), and Rodríguez Becerra (1992). 


\section{CARNIVAL Vocalization AND GENDER}

As mentioned, carnival minstrels have always been men -adults and adolescents. Although they have always participated as masqueraders, women in Andalusia have rarely composed or sung carnival songs, at least not since the 1920s when my samples begin. Costumes are still often transvestite for both sexes, but men more often cross-dress than do women, since women frequently chose costumes that accentuate rather than disguise their sex. These may be prima donnas, foreign princesses, exotic dancers and the like. For men, dressing up in the "colcha", or mother's bed linens, complete with false breasts and a skirt, is still practiced. Up until 1991, the last year I witnessed carnival, women still did not engage in the writing -even peripherally - of lyrics or their public performance. Carnival verbal discourse remains entirely a male preserve; women's participation in the creative role of wordsmithing is virtually nil. Led by their "maestro", the all-male groups meet a few weeks before carnival to begin work on the poems and to select targets. Some ad hoc, some consecrated by tradition, these cliques meet behind closed doors, concealing their work even from kinsmen, so that their lyrics are fresh for the debut during carnival. Women remain object and audience of these verbal barbs ${ }^{3}$.

People in Fuenmayor gave their own interpretations of this female abstention from the rhetoric of carnival, which I hasten to add is in no way enforced or policed by men. These local explanations usually have to do with the supposedly "natural" discomfort women feel at performing "Spicy" acts in public - the coplas being largely scatological or obsceneand the inherent modesty of women in public and their voluntary (and appropriate) withdrawal from such sexual indecorum. This is referred to locally as women's reticence to salir, or "go out". Las mujeres no salen, "Women don't go out", people say, No quieren, "they don't want to". People add that "women don't want to expose themselves in public", and "a woman can't sing spicy songs in public". I have raised this question of sex asymmetry in performance before (Gilmore, 1993), and I still do not have a satisfying answer to the problem of female self-removal from murga

3 In Western Europe, including southern Europe, men have been traditionally the comedians and satirists, female comics being relatively new and contingent on modernization. Clowns, too, have usually been exclusively male in the West; even female roles in folk burlesque are often played by transvestites (Counihan, 1985; Zapperi, 1991). This exclusion of women from burlesque may be a sequel to the sexual underpinnings of much of the world's humor, as both Freud (1905) and Bakhtin (1984) have argued, and hence to norms of female modesty and the resultant monopoly on sexual buffoonery by males, including female roles in ribald dramaturgy (Cf. Bricker, 1973). 
artistry. But it is clear that bawdy public speech is antithetical to norms of femininity in Andalusia, an attitude still adhered to, despite feminist advances in other areas, by both sexes. "Going out" and singing bawdy lyrics in public literally means emerging from the shell of the sociallyconstructed self, abandoning the constraints of normalcy; and this clearly symbolizes phallic assertion and bodily exposure, as Herzfeld notes in his study of gender, agency, and speech in Greece (1985). Such public agential modes are still proscribed for women in southern Spain, voluntary compliance included ${ }^{4}$.

Below, with brief commentary, I give some examples of "spicy" lyrics sung in Fuenmayor between the 1940s and most recently recorded in 1991. None of these songs are copyrighted. I record each song as collected in pamphlets and broadside sheets, including misspellings, Andalusianisms, and other solecisms. All translations are mine and are aimed at capturing sense rather than style. The authors are named in the accompanying notes. Since the material is undated, most dates are approximate, based on informants' best guesses. In content, one will notice, subtle (but sometimes obvious) encoded messages being communicated to women, all disguised by the "cover" of humor and allegory. The texts are multivalent and often contradictory: women are both weak and strong, passive and aggressive, modest and shameless. Men express different affective responses to these opposed "sides" of woman at different times, with the female object taking on the protean variety of male fantasy depending upon context. After all, this is carnival, when there are no contradictions. Given this freedom from quotidian logic, the songs give a strong impression of affective ambivalence: messages about self-restraint and warnings against sin are mixed

\footnotetext{
4 Recent studies of oral literature and ethnopoetics have focused on women's "vocality" as this relates to differential gender participation in public discourse and women's resistance to androcentrism (Herzfeld, 1991; Briggs, 1992; Kaeppler, 1993). In this context vocality may be defined as the degree to which people, women in this case, have power to influence community events through public rhetoric, dramaturgy, or ritual oratory, or as Briggs (1993:952) puts it, the ability to "constitute an economy of truth" through the spoken word. To be sure, verbal performance always promotes authority in social relations since it commands public attention, endowing the speaker with "agency" vis-a-vis passive others (Herzfeld, 1985). Bourdieu $(1977,1982)$ has argued that power to shape discourse includes the ability to command an audience within speech communities; recent ethnographic research seems to bear out such a relationship between authority and public performance (Bauman and Briggs, 1990:7778). In a study of Tongan women's genres, for example, Kaeppler (1993:475) notes that -The oratorical art is central to social activity - constructing and imposing hierarchy and political potency. This seems relevant for most contexts where public speech reproduces social hierarchy (Feld, 1990; Tolbert, 1990).
} 
with opposing messages that wink at and indeed encourage female promiscuity; all this of course reflects a contradictory attitude about both women and sexuality - probably universal themes. As Bakhtin (1984: 11-12) argues, carnival humor is always ambivalent: "its is gay, triumphant and at the same time mocking deriding. It asserts and denies, buries and revives. Such is the laughter of carnivaln.

Beyond the richly inventive metaphors for copulation which provide the necessary spice, the joke in each case is informed by serious satire about female frailty, repression and desire, and sexual politics. Note also how the male is given primacy, the active voice, or "agency", in Herzfeld's terms (1985), through various tropes of domination and control, shot through with erotic symbolizations and anchored in concrete imagery. Our first example mocks a girl of "high status".

Una niña de elevada distinción

fue a cortarse las melenas

a lo garzón.

El barbero "mu" tunante y diligente

me la puso en postura diferente.

Vaya salero:

la peló y la afeitó con esmero

y la niña de gusto bailaba,

cuando le pasaba

la brocha el barbero 5 .
A girl of the most high station went to the barber to have her bangs done in the newest Parisian fashion.
But the barber had other ideas and he got her in a certain position. How clever of him:
he gave her such a marvellous haircut that she started jumping for joy, especially when he used the barber's brush on her.

Obviously "going to the barber" can also mean having intercourse, just as "skinning the turkey" and a host of other phrases are euphemisms that cultivated women use for sex. The barber's instrument is of course his penis and jumping for joy (literally dancing with pleasure in the original) means climax. But what the song really does is to make a parodic appropriation of the bourgeois women's lexicon of sexual circumlocution to construct a male joke about mutual seduction. The tonsorial parody exemplifies what Bakhtin (1984:18-19) has called the "grotesque realism" of carnivalesque parody, which takes as its essential principle degredation, the lowering of all that is high, spiritual, abstract: "It is a transfer to the material level, to the sphere of earth and body in their indissoluble unityn. In the spirit of the carnivalesque, the maestro attributes concupiscent intent to the "lady", but the active voice - the power to act or to consummate an intention- is reserved for the (lower-status) male.

The following song employs a similar trope often encountered in Andalusian allegory: prurient fish metaphors, playing on the pun of

5 Written in the 1950 s by "Marín", and sung by the troupe led by Juanillo El Gato. 
"pescado" (fish) and "pecado". Again the women is presented as both naive and worldly, sexually repressed and salacious, and again in need of the male instrument to "fulfill" her by resolving her indicision, metaphorically to "fill her" with phallic foods. This montage exemplifies what Vasvari (1991:3) has called the "gastro-genital equivalences" of Spanish carnival, a motif we will return to.

Una niña muy bonita que a su madre le decía, que le comprara pescado que en la plaza se vendía. La madre por complacerla, compró lo que gustaba; y uno de ellos traía la cabeza desollada. La niña al verlo gritó, causa con mucho disgusto: A mí me gusta el pescado que de grande me dé susto. Mi novio tiene un cazón, se hincha la que lo come, y dicen que es de la grasa de los peces cabezones ${ }^{6}$.

\section{A pretty young woman} had a craving for fish, so she asked her mother to get her some in the market. To placate her, the old woman brought home some of what she wanted, one fish with the head peeled (or skinned). But her daughter said with much displeasure, I only like big fish that fill me up. Now, my boyfriend has a porgy that swells you up real big if you eat it, and they tell me that this swelling is due to the fluid (grease, ointment) that comes from fishheads.

"Peeled" or skinned fishes are erect penises, with the fish "head" emerging from the foreskin. Likewise the fish-oil stands for semen and the swelling of the one who swallows the juice refers to pregnancy, although the allusion of swelling can also imply detumescence.

Also employing a gastro-genital metaphor, the following song combines the "hunger" of repressed female desire with a favorite automotive trope for sexual intercourse in which the bumpy motorcycle ride serves as an easily identifiable allegory for copulation.

Venimos contentos del Jueves Lardero y hemos presenciado, por casualidad, un niño en su Vespa llevaba una cesta, una gran merienda y la novia detrás. Por la cuesta abajo, gritó la chiquilla:
One Shrove Tuesday

we were minding our own business when we ran into this guy on a Vespa carrying a picnic basket with his girlfriend on back. Then going downhill speedily, the girl shouts out, Slow down and watch out where you're going, for God's sake, Juan Jose, and try to avoid all this

6 Composed by Juanillo El Gato, circa 1960. 
¡Vete pa la senda,

Por Dios, Juan José,

y evita, si puedes,

esos traqueones!

Mira que los huevos

se van a romper.

$\mathrm{Y}$ el conductor,

de tanto saltar la Vespa,

se le salió

el chorizo de la cesta.

Y ella exclamó:

Malo se presenta el plan,

con los huevos rotos

y sin el chorizo,

¿qué vamos a merendar? ? great shaking and bumping, because the eggs are going to break! Well, from all that jerking and bouncing about of the Vespa the driver's sausage flew out of his basket. And the girl then exclaimed, Hey, this is ruining our picnic plans: if the eggs get broken and without any sausage, how are we going to have a picnic?

Eggs and sausage stand for the testicles and penis (women often decorously use "huevos" in place of "cojones" for "balls"). The shaking and vibrating is foreplay, and the girl is worried that her lover will not bring her to orgasm unless he slows his motor down. The song portrays the woman as "hungry" (for sex) but unsure of her impulses, a common enough representation of female "weakness" throughout carnival versification. The deeper structure again suggests the romantic complicity of women and their supposedly insatiable appetite for the amorous nourishment provided by the male; what this does is to enact a symbolic reversal of the actual male dependency upon women for actual food. Again, the grotesque realism of carnival metaphors works to imagine the male as possessor of the sexual energy (or sustenance) that animates the object/ subject relation and the sense gratification expressed in carnivalesque slapstick: it is his motorcycle that gives his girlfriend "the ride", and it is his organ that provides the erotic nourishment. The woman is both needful and passively recipient, the male active and provisioning. This phallocentric vision reverses the normal oral dependency relations in Andalusia that bind men, in childlike fashion, to wives and mothers as the purveyors of cooked food, since men do not do kitchen work ${ }^{8}$.

Again using an inversive alimentary trope for the helpless hunger of desire and reversing relations of oral dependency, the following song plays on the same theme of women's conflicted impulses and the virile response of the male. This response is both peremptory and minatory.

7 Composed by Félix "El de la Gazpacha", circa 1967.

8 For a discussion of women's "subordination" of men through their control of food preparation in Mediterranean societies, see Pitkin (1985:214) and Counihan (1988:52-54). 
Y una moza de servicio que iba dándose cartel, por leche una mañana para tomar el café. Como iba tan "deprisa. la muchacha preguntó y como no estaba el cabrero ella misma ordeñó.

Estando ordeñando le dijo el muchacho; Cuidado chiquilla que ordeñas el macho?.
One morning a servant girl went out in great hurry to buy some milk for coffee. Being very distracted she asked for the goatherd but since he did not answer she started milking by herself. But she grabbed the wrong thing and the young man (goatherd) said: careful now, girl, or you'll milk my manhood.

The song plays on the polysemous verb "ordeñar", to milk a cow or other animal, and also to rub or manipulate an object. For example, using the same verb, Andalusians speak of "milking" the branches of an olive tree during the harvest, to collect the fruit or "seed". Drenched in sexual symbolism, the scene depicted is a pastiche of mixed bodily metaphors; what is less apparent is the moral message to the effect that the serving girl, going about her business blindly (but unconsciously willing), stimulates the macho (goat or man), thereby initiating his macho response, expressed as a warning. The serving maid is portrayed as sexually provocative, but the male retains a privileged position of both genital domination and moral authority.

In a similar vein, the following song (circa 1950) turns a minor medical problem, a splinter "in a sensitive spot", into a crude joke about sexual seduction:

\author{
Limpiando los cristales \\ Paquita se cayó, \\ $\mathrm{y}$ en delicado sitio \\ un vidrio se clavó. \\ Al hospital la llevan \\ al Hospital Central, \\ y el médico de guardia \\ l'ha querido examinar. \\ ¡Esto es muy grave! \\ le dijo el practicante, \\ con algodón se cura \\ cuanto antes. \\ Viendo Paquita \\ que no se le curó,
}

\author{
Cleaning windows one day, \\ Paquita fell down \\ and a little glass splinter \\ got stuck in a very delicate place. \\ They took her to the hospital \\ the Central Hospital, \\ and the medic on duty \\ wanted to examine her. \\ This is very serious, \\ said the intern, \\ I'll use a cotton swab to \\ cure this right away! \\ But seeing that the bandage \\ didn't cure her wound,
}

9 Composed by Juan "El de la Harina*, in the 1930 s. 
cogió el médico el paquete y la herida le tapó ${ }^{10}$. the doctor grabbed the "package" (male organs] and covered up the wound with that.

The following song, dating from the 1940s, employs the a conveyance metaphor, here the bicycle, which was the poor man's vehicle of necessity during the shortages of the postwar period. In explanation of this ubiquitous transportation imagery, people say that riding front-to-back is very much like sex, because a man and a woman are "bouncing" in unison with the man in control (or "driving", also alluding to copulation). Thus the newly popular bicycle, driven by the male, provided a perfect metaphor for an androcentric vision of sexuality before cars and motorcycles (Gilmore, 1983).

Se ha puesto muy popular

la bicicleta, ya las mocitas de Fuenmayor están muy contentas.

Cuando salen de paseo suelen decir:

Voy en busca de mi novio que ha comprado una y me va a subir.

Salieron una buena tarde a echar un paseo, hacia el "Barrancón". Tuvieron una avería $\mathrm{y}$ al suelo cayeron rodando los dos. Préstame por Dios auxilio y muévete Nicolás, no sea que pase alguno y vea que tengo la bomba "claváw"
Bicycles have become very popular indeed, and all the gals of Fuenmayor are very happy about it. Whenever they go for a walk they say:

I'm going to find my boyfriend, he just bought a bike and I'm going to get on with him.

Well, this couple we know went out one fine evening to take a ride on the bike, out to the "Ravine" [outlying area] they went. But they hit a bump and fell down on the ground, rolling on top of each other.

For God's sake, Nicholas, help me, she says. and move over a little, please, someone might come by and see that I've got the bicycle pump inserted [impaled, stuck in.]

Resorting to obvious "downfall" imagery (which may be read as both willing capitulation and disgrace), the songs warns women that forwardness will lead to serious consequences with pointed objects. But it is an ambivalent warning, the implication being of women's complicity, both a warning and a wish about female receptiveness and, of course, the pleasure in sex provided by the virile "driver".

The following song makes fun of female sexual "weakness" through veterinary images, also common in Andalusian coplas. In Andalusian sexual

\footnotetext{
10 Lyrics by Félix "El de la Gazpacha*.

11 Composed by Juanillo El Gato.
} 
slang, "rabbit" means vagina and "gruel" (or serum) stands for semen. Like many other bawdy parodies, this brief lyric makes the oft-repeated point that female sexuality, while vital and "hot" (to use the favored term), is so repressed by convention as to become deformed into neurotic symptoms (the rabbit's illness), requiring the tutelage of a man to achieve satisfaction, or in the animal metaphor, health. Thus the singer again gives to men not just agential primacy in sex, but also wisdom and restorative craft, the woman reduced to object, as in the doctor/patient relationship. Common to much of this carnival imagery, the active/passive rhetoric reminds one of the "seed and soil" imagery that Delaney (1991) reports from rural Turkey, in which the plow symbolizes the male principle, and the fertile but inchoate earth the female. This subject/object metaphor is common in the masculine appropriation of the active voice in sex, as in other things.

Mariquilla tenía un conejo

la más de gracioso que lo he visto.

Yo, asombrao, me dije ¡vaya!

la hambre que tenía que pasar

yo no he visto en otro animal.

Yo le pongo de pronto una inyección,

sí, es de suero bastante mejor.

Con la inyección que le hemos puesto

ya está el conejo repuesto ${ }^{12}$.
Little Mary had a bunny rabbit, the funniest little thing I ever saw. I was surprised at how skinny it was and I said to myself, Gosh what hunger this poor thing must have suffered! So I gave it an injection of the very best serum just as fast as I could.

And wouldn't you know it?

With that injection I gave it, that little rabbit revived in a wink.

We now move to songs that carnivalize gender from other, and seemingly obverse, angles. The following copla, from the mid-1970s, takes "modern" girls to task for their provocative miniskirts and go-go fashions. Written and sung by conservative older men, the lyrics attack the immodesty of young girls in a period of social change, with the message that such behavior will drive suitors away rather than attract them. So again women are given the implicit understanding that serious judgments (marriage being the most serious in life) are made by men; although here the demand is for prudence rather than promiscuity.

Este año las mocitas

este año las mocitas

le han dado por llevar

colgada una cadenita

y unas medias muy calás.
This year, this year, the girls are all wearing hippy beads and see-through blouses.

12 The author of this ditty, composed in the 1950s, is unknown. My thanks go to Antonio Siria, José María Lora Sánchez and Sebastián Lora Sánchez for their help in reconstructing the verses. 
Por las calles ellas

van diciendo vida mía

quiero ser ye-yé,

llevando una minifalda

llevando una minifalda

que el ombligo se le ve

parece el mono en un circo

cuando charlando se ven.

Cualquiera llega

a pedirle un paseíto

con la cara que suelen poner.

$\mathrm{Si}$ es que eres un rebuscao

pues no llegues

y quedarás mejor.

Lástima pintura

que te pones

y no sabes lo fea que estás ${ }^{13}$.
They sashay through

the streets exclaiming

Oh, my, how I want

to be a go-go girl.

Wearing miniskirts, miniskirts, that barely cover their navel, they look just like circus monkeys

chattering through the streets.

Who is going to ask you out

with that face you put on?

Hussy, you're like a left-over (rorten) olive after the gleaning,

no man will choose you.

With all that paint

you shamelessly slap on your face.

You don't know how ugly you look.

The following song, from the early 1980s, again attacks "liberated" women as shameless and sexually provocative. The message once again places the onus on the woman for the predation of the male which is inspired by her immodesty. The lyrics use the favorite vehicular metaphor for sexual seduction, with the man once again in the driver's seat, in fact, the man's "hard object" becomes the driveshaft.

Una noche que llovía

un murguista se encontró

una pareja de novios

que le llamo la atención.

Ella buscaba las bragas

debajo de un automóvil, y le hecho mano al embrague

y dijo usted me perdone

el chofer que estaba dentro.

La cogió por la cintura

y se la sentó en la falda;

le cogió una cosa dura.

$\mathrm{Y}$ cuando salen del baile

vienen jartas de cubatas,

no saben las infelices

que pueden meter la pata.

Deben de tener un castigo

el que da esa libertad

así no habría en el mundo

mujeres tan desgraciás ${ }^{14}$.
One rainy night

one of our troubadours here

saw a couple that

caught his attention.

She was looking for her panties

underneath a car,

and she grabs the clutch by mistake

and the driver inside says,

hey, pardon me, lady.

He grabs her by the waist

and sits her down on his lap,

and the next thing you know

she's grabbing something hard.

When these modern girls leave

their midnights parties

all liquored up,

they don't know what trouble

they can get into.

There should be a severe punishment meted out to whoever gives them

\footnotetext{
13 Composed by Francisco Caro "El Quico", and sung by "Los Elegidos".

14 Composed by "Los Andaluces".
} 
this licentious liberty.

In the whole world there are no women more disreputable than in this town.

While the song mentions no one specifically, it is clear that those responsible for the young women's "disgrace" are their over-liberal fathers and brothers who "permit" them this scandalous freedom. More masculine control is needed, the poet pleads, because a wayward young women is fair game to male predation, the lyrics conveying the entire panoply of Andalusian double sexual standards. Touch the gearshift, the message warns fatuously, and you start the engine; the blame is yours. The woman who "starts the car", is always to blame in the case of an accident, or overheating, as the case may be.

The next songs leave off the sexual theme and enter the parallel universe of male complaints about female duplicity and insensitivity to men's domestic needs. These are funny to the audience because they invoke the always-hilarious domestic comedy with its stock stereotypes: the put-upon henpecked husband and the shrewish grasping wife who is also a poor housekeeper. The following song reviles women for ignoring their obligations, for being bad cleaners, for bossing their husbands, and for not properly attending their husbands' personal needs.

Me ofrecen una novia con salero pero yo no la quiero porque te voy a decir, mientras me encuentre yo soltero hago lo que quiero y nadie manda en mi. De primera parece una cosa buena moza como tú la ves, y se casan y nunca se lavan y salen diciendo pues yo ya pasé.

Si eso fuera una sandía que se pudiera calar antes de casarse niña enseñate tú a lavar, que es una vergüenza niña (bis) como tu marido va.

Por eso darse cuenta muchachas ya sabéis lo que pasa si se queréis casar; algunas tenéis la ajuar comprada y no os sirve de nada por no saber lavar.

Aplicarse la que quisiera casarse, pa que pueda su casa llevar que parece mentira chiquilla que vaya el marido como algunos van.
I was offered a beautiful fiancee

but I turned her down for reasons I'll now relate. While I remain a bachelor,

I do what I want and no one orders me about. At first glance a woman seems like a good thing, lovely to look at, good and sweet, but after they get married they never clean house, saying I'm above all that now.

If only a woman was like a watermelon that you could tap to test its flavor. Before you marry, girl, lean to wash and care for your husband; its a damn shame how you neglect them. So take care girls, if you want to marry you must learn what marriage is all about. Some of you have your trousseau already made up but its all to no avail unless you learn housekeeping. Apply yourself, girls, if you want a husband, learn to clean house, you're deceiving yourself 
El otro día vimos a uno que estaba recién casado, y llevaba la chaqueta que era un papel de pescado. El se fue buscando lana (bis) pero salió trasquilao ${ }^{15}$. if you think you'll keep a man

if you neglect your duties.

Why, the other day, we saw one poor guy recently married, he was, and instead of a coat, he was wearing a smelly old fish wrapper: he went looking for fleece in marriage but instead came away shorn!

The last song scolds women from an slightly different angle. Written in the 1960s, during the highpoint of the labor emigration to northern Europe, it chastises wives for exploiting their husbands economically, forcing them into alien labor, ignoring their needs, and caring only for money. The theme is foreign emigration, which working-class men were forced to embark upon to make ends meet at that time. Naturally, most men hated and feared leaving home, but felt doing so to be part of the breadwinning role, which they refer to as a man's "sacrifice" for the family. This reminds one of the Italian men reported by Davis (1973:94-95) in the town of Pisticci who referred to their work as a "Sacrifice", saying, "If it were not for my family, I'd not be wearing myself out (non mi sacrifico). In Spain, men also remonstrate that they must "sacrifice" in order to satisfy their wife's insatiable desire for consumer goods. So here the man is portrayed as the victim of female perfidy, forced from his natal village into a hard life of thankless toil in foreign lands.

Esto de los emigrantes se ha puesto mu popular todo el que va a Alemania una casa quié comprar. Otros se van a Suiza por ver lo que pasa allí, que quiere comprar una vaca la vaca la dejo aquí. La vaca que tú has dejao todo el día dando suspiros no me importa que tú vengas pero mándame los giros. Si no me mandas los giros no me tengas que escribir cojo la ropa y me marcho a Barcelona a servir.
This labor emigration stuff has become very popular these days; Everyone's going to Germany to make enough dough to buy a new house. Others are going to Switzerland to see what's available there, some to buy a milk cow to leave behind here in Spain. That cow you bought, says the wife, sits around doing nothing, moaning just like you do all the time. I don't care if you never come home, just send me those remittances. If you don't send me money don't bother writing, I'll just go to Barcelona and

15 Composed by Marcelino Lora around 1965, and sung by the murga "Alegría Fontaniegaw. 
$\mathrm{Ni}$ que te vayas a Alemania ni a Suiza ni a Belén la mujer no quiere a nadie no quieren más que el parné. Eso la pasa a la tuya a la mía y a las demás en viendo billetes verdes mire que amorosas estén. Tiendo billetes verdes esté visto y aprobao eres bonito y gracioso sabes más que un abogao. El hombre que sea mu feo $y$ no encuentre casamiento teniendo billetes verdes pierden el conocimiento. Aquí termina la copla esta es la realidad, mire como toas se rien porque saben es verdad ${ }^{16}$. get a job myself.

So listen, men, no matter where you go, Germany, Switzerland, or Belen [Spanish resort] women don't care about you, all they want is your money. This is true of my wife, yours, and everyone else's;

when they see those greenbacks [1000 peseta bill] look how amorous they suddenly become. If you have greenbacks, why, then you're good-looking, you're Mr. Right, you're romantic, you're charming, you're smarter than a lawyer.

A really ugly guy who can't get a woman to marry him, just needs some of those greenbacks, and suddenly he's an Adonis.

Well, this song is done, this is the way it is; look how everyone is laughing because you all know it's true.

\section{CONCLUSIONS}

Performed during a liminal period of ritual disinhibition, these doggerel verses represent the masculine monopoly of the critical voice of public judgment, facilitating an appropriation of the active voice - through verbal artistry. The poets of Fuenmayor fault woman for a welter of sins, both sexual and ethical, men retaining the authority to "imagize" women as both object of desire and of derision. Bauman and Briggs (1990:76) say that the performance of verbal art "is a mode of social production", closely allied to the political economy of power and community authority. Disguised by comic imagery, sweetened by laughter, the coplas, full of appealing tropes and ribald characterizations, provide the male singers with control over what one might call "the means of seduction". Thus the singer derives both the power and the opportunity to write the script of sexuality, solidifying claims to moral sovereignty as poet and man. Yet carnival protocols write a script that is as ambiguous as it is controlling. As Heath (1994:95) argues in her analysis of women's dance in urban Senegal, such thematic ambiguity reflects and publicizes "a central contradiction in gender relations", which is the antithesis between phallic assertion and the need to shelter

16 Composed by Marcelino Lora. 
kinswomen from the predation of others, as well as ambivalence about untrammeled female sexuality - the libidinized image of woman bursting the bounds of convention. Balanced uncertainly between power and weakness, masculine discourse spawns an affective ambiguity that furnishes the underlying motif and chaotic reversals of carnival burlesque, as "Scatology and obscenity reaffirm the vital body" (Hutcheon, 1985:71).

Irresoluble in thought, this conflict between fleshly desire and denial, between dependence and "masculine protest" in Adlerian terms, finds resolution through salacious laughter, specifically in sexual travesty, wherein inner contradictions conflate pleasurably in bizarre corporeal associations. In this topsy-turvy world, food and sexual hunger are equated in the gastro-genital symbolism beloved of the Andalusian poet (Vasvari, 1991); the male genitals transmute into fishes, eggs and sausage, a cotton swab, a barber's brush, or the stiff gearshift of a car. A bicycle ride becomes erotic foreplay, a rabbit becomes a vagina sick with sexual longing; milk for morning coffee inspires sexual fantasies. This erotic bricolage is not simply the negation of the normal order, but the creative fusing of "the other side" of that which is denied with the denial itself, a creative deformation accomplished formally by the means of florid symbolizations, Bakhtin's (1984:410) grotesque realism. Presenting discordant messages about woman's "nature", the texts represent the female self as a riddle or enigma, promoting mastery and masculine mastery, for the messages reconfirm the Freudian notion of female sexuality as a psychological dark continent: that is, the very scenario that encourages man to explore and conquer it (Wills, 1989:144).

As Bakhtin notes (1984:240), the ambiguities of the female object as represented in the minstrels' words are exactly the qualities which characterize carnival in general, for they are both positive and negative, gratifying and denying at the same time, so that woman's body furnishes both the arena and the materials for symbolic deformations of society.

The popular tradition is in no way hostile to woman and does not approach her negatively. In this tradition woman is essentially related to the material bodily lower stratum; she is the incarnation of this stratum that degrades and regenerates simultaneously. She is ambivalent. She debases, brings down to earth, lends a bodily substance to things, and destroys; but, first of all, she is the principle that gives birth.

Both body and text are carnivalized in the linguistic abolition of the central contradiction of gender. This abolition of affective opposites, of desire and repulsion, of neediness and autonomy, is what Barthes calls figuration (1976:55). "Figuration is the way in which the erotic body appears...in the profile of the text" in protean forms. Figuration relaxes the 
barrier between the represented object and the audience, creating a polymorphous unity of bodies that transforms the relations among subject, object, and symbol. Like language itself, female "nature", both in its erotic and nourishing (maternal) guises, is the "inchoate object" (Fernandez, 1986:31-32), that it carnivalized, that is atomized into a wonderland of symbols, reconstructed through the author's verbal virtuosity.

Building on the work of Barthes and Bakhtin, the critic Linda Hutcheon (1985) develops a general theory of carnivalesque parody that is relevant in this process. Her argument centers on the paradoxical dualism of the ironic - the central aesthetic formula of carnivalesque parody. The paradox of parody is that is revolutionary and socially conservative at the same time: eits transgression is always authorized... even with a critical difference parody reinforces" (Hutcheon, 1985: 26). Thus there emerges the underlying gender didacticism of carnival burlesque: despite its comic inversions, its irreverent tropes, its subversiveness,

[...] parody's transgressions ultimately remain authorized - authorized by the very norm it seeks to subvert. Even in mocking, parody reinforces; in formal terms, it inscribes the mocked conventions onto itself, thereby guaranteeing their continued existence (Hutcheon, 1985:75).

The maestro of carnival is both clown and judge, subverter and upholder of tradition. He is the master of both words and things, for in overthrowing the boundaries of speech he has overthrown the sovereignty of the object.

\section{BIBLIOGRAPHY}

Aguilar, José, 1983: Los Carnavales y la Murga Sevillana de los Años 30, Sevilla: Ayuntamiento de Sevilla.

ALMAGRO SÁNCHEZ, Rosalía, et al., 1990: "Los carnavales en nuestros pueblos: Alcalá de los Gazules y Paterna de Rivera", El Folk-Lore Andaluz, 5, 121-144.

BAKHTIN, MiKHAIL, 1984: Rabelais and His World. Transl. by H. Iswolsky, Bloomington: Indiana Univ. Press.

BARTHES, ROLAND, 1976: The Pleasure of the Text. Transl. by R. Miller, London: Cape.

Bauman, Richard and Charles L. Briggs, 1990: "Poetics and Performance as Critical Perspectives on Language and Social Life, Annual Review of Anthropology, 19, 59-88.

Bourdieu, PIERre, 1977: Outline of a Theory of Practice. Trans. by R. Nice, Cambridge: Cambridge Univ. Press.

- 1982: "The Economics of Linguistic Exchanges", Social Science Information, 16, 645-668. 
Brandes, Stanley H., 1980: Metaphors of Masculinity: Sex and Status in Andalusian Folklore, Phila.: Univ. of Pennsylvania Press.

- 1988: Power and Persuasion, Phila.: Univ. of Pennsylvania Press.

BRICKER, VICTORIA REIFLER, 1973: Ritual Humor in Highland Chiapas, Austin TX: Univ. of TX Press.

BriggS, Charles L., 1992: "Since I Am a Woman I will Chastise my Relatives: Gender, Reported Speech, and the (Re)Production of Social Relations in Warao Ritual Wailing, American Etbnologist, 19, 337-361.

- 1993: «Personal Sentiments and Polyphonic Voices in Warao Women's Ritual Wailing: Music and Poetics in a Critical and Collective Discourse", American Anthropologist, 95: 929-957.

BRISTOL, MiCHAEL D., 1984: Carnival and Theatre: Plebeian Culture and the Structure of Authority in Renaissance England, NY: Methuen.

Caraveli, AnNa, 1986: "The Bitter Wounding: The Lament as Social Protest in Rural Greece, in J. Dubisch (ed)., Gender and Power in Rural Greece, Princeton: Princeton Univ. Press., 169-194.

Caro Baroja, Julio, 1984: El Carnaval: Análisis Histórico-Cultural, Madrid: Taurus (1965).

CheCA, Francisco, 1992: "El humor andaluz: ¿identidad de un pueblo?», El Folk-Lore Andaluz, 8, 55-84.

Couniham, Carole M., 1985: "Transvestism and gender in a Sardinian carnival", Anthropology, 9, 11-24.

- 1988: "Female identity, food, and power in contemporary Florence", Anthropological Quarterly, 61, 51-62.

DAvis, JOHN, 1973: Land and Family in Pisticci, London: Atholone Press.

Delaney, CAROL, 1991: The Seed and the Soil: Gender and Cosmology in Turkish Village Society, Berkeley: Univ. of CA Press.

DuBISCH, Jill, 1991: "Gender, Kinship, and Religion: "Reconstructing" the Anthropology of Greece", in P. Loizos and E. Papataxiarchis (eds.), Contested Identities: Gender and Kinship in Modern Greece, Princeton: Princeton Univ. Press., 29-46.

DRIESSEN, HENK, 1983: "Male Sociability and Rituals of Masculinity in Rural Andalusia", Anthropological Quarterly, 56: 125-133.

Fernandez, James W., 1986: Persuasions and Performances: The Play of Tropes in Culture, Bloomington: Indiana Univ. Press.

Freud, Sigmund, 1905: Jokes and Their Relation to the Unconscious, Transl. by J. Strachey, NY: Norton [1950].

Feld, Steven, 1990: Sound and Sentiment: Birds, Weeping, Poetics, and Song in Kaluli Expression, Phila.: Univ. of Pennsylvania Press.

García DE Diego, Pilar, 1960: "Censura Popular", RDTP, 16, 295-331.

GILMORE, DAVID D., 1975: “Carnival in Fuenmayor", Journal of Anthropological Research, 31, 331-349.

- 1980: People of the Plain: Class and Community in Lower Andalusia, NY: Columbia Univ. Press.

- 1983: :Sexual Ideology in Andalusian Oral Literature», Ethnology, 22, 241-252.

- 1987: Aggression and Community, New Haven: Yale Univ. Press.

- 1988: "Politics and Ritual: Fifty Years of Andalusian Carnival", Iberian Studies, 17, 34-49.

- 1993: "The Democratization of Carnival", Anthropological Quarterly, 66, 37-47. 
González Troyano, Alberto et al., 1983: Carnaval en Cádiz, Cádiz: Ayuntamiento de Cádiz.

HeAth, DeBorah, 1994: "The Politics of Appropriateness and Appropriation: Recontextualizing Women's Dance in Urban Senegal,, American Ethnologist, 21, 88-103.

HeRZFeld, MiCHAEL, 1985: «Gender Pragmatics: Agency, Speech, and Bride-Theft in a Cretan Mountain Village», Anthropology, 9: 25-44.

- 1991: "Silence, Submission, and Subversion: Toward a Poetics of Womanhood", in P. Loizos and E. Papataxiarchis, Contested Identities, Princeton: Princeton Univ. Press, 79-97.

- 1993: :In Defiance of Destiny: The Management of Time and Gender at a Cretan Funeral, American Ethnologist, 20, 241-255.

Huizinga, Johann, 1955: Homo Ludens: A Study of the Play Element in Culture, Boston: Beacon Press.

Hutcheon, LINDA, 1985: A Theory of Parody: The Teachings of Twentieth-Century Art Forms, NY: Methuen.

KAePpleR, ADRIENNE L., 1993: "Poetics and Politics of Tongan Laments and Eulogies", American Etbnologist, 20, 474-501.

Kertzer, David I., 1988: Ritual, Politics, and Power, New Haven: Yale Univ. Press.

Le Roy Ladourie, Emmanuel, 1979: Carnival in Romans, NY: George Braziller.

Loizos, Peter and Evthymios Papataxiarchis, 1991, "Gender in Kinship and Marriage and Alternative Contextsn: in P. LoIzos and E. PAPATAXIARChIS, (eds.), Contested Identities, Princeton: Princeton Univ. Pres, 3-28.

MADDOX, RICHARD, 1993: El Castillo: The Politics of Tradition in an Andalusian Town, Urbana IL: Univ. of IL Press.

MinTZ, Jerome R., 1982: The Anarchists of Casas Viejas, Chicago: Univ. of Chicago Press.

Mitchell, Timothy J., 1988: Violence and Piety in Spanish Folklore, Phila.: Univ. of Pennsylvania Press.

PITKIn, DONALD, 1985: The House That Giacomo Built: History of an Italian Family, 1898-1978, NY: Cambridge Univ. Press.

Pitt-Rivers, Julian A., 1971: The People of the Sierra, 2nd Edn. Chicago: Univ. of Chicago Press.

Rodriguez, SYlVIA, 1991: "The Taos Matachines: Ritual Symbolism and Interethnic Relations", American Etbnologist, 18, 234-256.

Rodríguez Becerra, Salvador, 1985: Las Fiestas de Andalucía, Sevilla: Biblioteca de Cultura Andaluza.

- 1992: "El carnaval y lo carnavalesco en las fiestas en Andalucía", in Actas del Congreso del Carnaval, Cádiz: Ayuntamiento de Cádiz.

SEREMETAKIS, C. NADIA, 1991: The Last Word: Women, Death, and Divination in Inner Mani, Chicago: Univ. of Chicago Press.

TAGGART, JAMES, 1992: "Gender Segregation and Cultural Constructions of Sexuality in Two Hispanic Societies", American Ethnologist, 19, 75-96.

TOLBERT, ElizABETH, 1990: "Magico-Religious Power and Gender in the Karelian Lament", in M. Herndon and S. Ziegler (eds.), Music, Gender, and Culture, Berlin: Institute for Comparative Music Studies, 41-56.

URBAN, GREG, 1988: "Ritual Wailing in Amerindian Brazil", American Anthropologist, 90, 385-400.

VASVARI, LOUISE O., 1991: "The Battle of Flesh and Lent in the LLibro de Arcipreste": Gastro-Genital Rites of Reversal", La Coronica, 20, 1-15. 
Wills, Clair, 1989: “Upsetting the Public: Carnival, Hysteria, and Women's Texts", in K. Hirschkop and D. Shepherd (eds.), Bakbtin and Cultural Theory, Manchester: Manchester Univ. Press, 130-151.

ZAPPERI, ROBERTO, 1991: The Pregnant Man, Transl. by B. Williams, NY: Gordon and Breach.

\author{
DAVID D. GILMORE \\ State University of New York \\ at Stony Brook
}

Este artículo presenta unas coplas de chirigota compuestas por desempeño público durante el carnaval en una villa agraria de la provincia de Sevilla. Las coplas están compuestas entre los años 40 y 90 . Representando un género folklórico burlesco social específicamente andaluz, las coplas son una prerrogativa solamente masculina, escritas por los "maestros de murga" e interpretadas por cantores masculinos ("murguistas"). Basadas en imágenes eróticas, metáforas genitales y alegorías obscenas, las letras comunican una ideología masculina sobre la sexualidad, las relaciones entre el hombre y la mujer y la domesticidad. Concluye el artículo con una breve interpretación de las letras de chirigota, basándose el análisis en el concepto de "realismo grotesco" propuesto por el crítico ruso Bakhtin.

This paper presents a series of comic coplas written for public performance during carnival in agrotown in Seville Province, Andalusia. The songs date from the 1940 s to the 1990s. Their production is a male prerogative: composed by male "maestros", they are sung by male troubadours. This is a specifically Andalusian genre of social burlesque that takes woman as its subject: wives, lovers, mothers-in-law. The lyrics use erotic imagery, genital tropes, and obscene allegories to covey the prevailing masculine ideology concerning sexuality, male-female politics, and domestic relations. The paper concludes with a brief interpretation of the style and symbolism of the Andalusian carnivalesque, borrowing from the critic Bakhtin's concept of "grotesque realism. 